\title{
Pathways of the Modified Atlantic Water across the Strait of Sicily
}

\author{
(C) I. Ben Jaber, J. Abdennadher, M. Boukthir, 2014 \\ Preparatory Institut for the Engineer Studies of Tunis, Tunisia \\ Received 10 January 2014 \\ Presented by Editorial Board Member O. M. Rusakov
}

\begin{abstract}
Цель данного исследования — изучение среднемасштабной динамики, а также динамики суббассейнового масштаба в Центральном Средиземноморье и выяснение маршрутов атлантических вод в этой области при помощи высокоразрешающей численной модели вихреразрешающего простейшего уравнения. Сезонная изменчивость Авух потоков модифицированных атлантических вод, пересекающих Сицилийский пролив, существенно различается. Главный поток вдоль побережья Туниса, дающий начало Атлантическому тунисскому течению, сильнее, чем Атлантический ионийский поток (АИП) с осени до весны. Атлантическое тунисское течение, которое, по-видимому, присутствует в течение года, по результатам моделирования характеризуется высокой пространственной и временной изменчивостью. Высокоразрешающая модель способна хорошо воспроизводить течение и изменчивость АИП, включая такие ассоциирующие характерные структуры, как Эдвенче Бенк Вортекс, Молтиз Ченнел Крест, Иониан Бенк Вортекс и выброс в северную часть Ионического моря.
\end{abstract}

Ключевые слова: Центральное Средиземноморье, сезонная изменчивость, атлантические воды, мезомасштаб.

Мета цього дослідження - вивчення середньомасштабної динаміки, а також динаміки суббасейнового масштабу в Центральному Середземномор'ї та з'ясування маршрутів атлантичних вод в цій області за допомогою високодозвільної чисельної моделі вихорораздільного простого рівняння. Сезонна мінливість двох потоків модифікованих атлантичних вод, що перетинають Сицилійську протоку, істотно розрізняється. Головний потік уздовж узбережжя Тунісу, що дає початок Атлантичній туніській течії, сильніше, ніж Атлантичний іонійський потік (АІП) з осені до весни. Атлантична туніська течія, яка, мабуть, присутня впродовж року, за результатами моделювання характеризується високою просторовою і тимчасовою мінливістю. Високороздільна модель здатна добре відтворювати течію і мінливість АІП, включаючи такі асоціюючи характерні структури, як Едвенче Бенк Вортекс, Молтіз Ченнел Крест, Іоніан Бенк Вортекс і викид в північну частину Іонічного моря.

Ключові слова: Центральне Середземномор'я, сезонна мінливість, атлантичні води, мезомасштаб.

Introduction. The variability of the water masses properties and circulation characteristics in the Central Mediterranean Sea has been largely investigated in the past years through hydrographical observations [Manzella, La Violette, 1990; Sammari et al., 1999], sub-surface currentmeters data [Gasparini et al., 1999; Vetrano et al., 2004; Astraldi et al., 2005], Lagrangian drifters [Poulain, Zambianchi, 2007] and high resolution numerical simulations [Onken et al., 2003; Sorgente et al., 2003; Béranger et al., 2005]. However, available observations are often characterized by poor spatial and temporal coverages, and are usually confined to the Italian continental shelves while there is lack of observations over the Tunisian and Libyan continental shelves. Only few datasets have adequate temporal and spatial resolution to capture the mesoscale in local areas [Lermusiaux, Robinson, 2001]. It is important to note that very few data have been collected along the African coasts which imply a substantial under sampling of Tunisian and Libyan waters on the shelf slope and on the continental shelf. For example, the current off Cap Bon (Tunisia) may be truncated by the sampling [Béranger et al., 2004]. In this context, numerical model simulations constitute an important tool to fill the observational gaps and to study the spatial and temporal ocean circulation variability.

The Seasonal circulation of the central Mediterranean Sea was numerically investigated by 
many authors [Sorgente et al., 2003; Béranger et al., 2005; Astraldi et al., 2002]. Although these efforts allowed understanding a lot about this circulation, some interrogations remain without convincing answers. One of the main objectives of this work is to examine the time and spatial variability of the Atlantic Tunisian Current (ATC), which is not well documented. Moreover, its long-term variability in space and time is only inferred from surface drifters [Poulain, Zambianchi, 2007] and SST satellite images [Hamad et al., 2005]. To this end, we have investigated the seasonal variations of the surface circulation in the central Mediterranean Sea from a high resolution eddy-resolving primitive equation numerical model (ROMS).

Model setup. Model description. The model used in this study is based on the Regional Oceanic Modelling System (ROMS), a three-dimensional primitive equation, finite difference hydrodynamic model. ROMS solves the primitive equations in an earth-centred rotating environment, based on the Boussinesq approximation and hydrostatic vertical momentum balance. ROMS uses stretched, terrain-following coordinates in the vertical and orthogonal curvilinear coordinates in the horizontal. ROMS is a split-explicit, free-surface oceanic model, where short time steps are used to advance the surface elevation and barotropic momentum equations, with a much larger time step used for temperature, salinity, and baroclinic momentum. ROMS employs a special 2-way time-averaging procedure for the barotropic mode, which satisfies the 3D continuity equation. For further details and more complete description of the model, the reader is referred to [Shchepetkin, McWilliams, 2005]. The vertical mixing of momentum, heat, and salt are determined by a turbulence submodel known as the Mellor-Yamada level 2.5 turbulence closure scheme [Mellor, Yamada, 1982]. Horizontal mixing uses Smagorinsky diffusivity where the horizontal mixing coefficient depends on the grid size and horizontal shear as well as an arbitrary constant.

The surface boundary condition for momentum is:

$$
\left.K_{M} \frac{\partial \mathbf{u}}{\partial z}\right|_{z=\eta}=\frac{\tau}{\rho_{0}}
$$

where $\tau$ is the wind stress vector, $K_{M}$ is the vertical kinematic viscosity, $\rho_{0}=1025 \mathrm{~kg} \cdot \mathrm{m}^{-3}$ is a reference density and $\eta$ is the free surface elevation. The wind stress components use a drag coefficient $\mathrm{C}_{\mathrm{d}}=\mathrm{C}_{\mathrm{d}}\left(\mathrm{T}_{\mathrm{a}}, \mathrm{T}, \mathrm{W}\right)$ as function of the wind amplitude $(\mathrm{W})$, the air temperature $\left(\mathrm{T}_{\mathrm{a}}\right)$ and the sea surface temperature predicted by the model (T) following the polynomial approximation given by [Hellerman, Rosenstein, 1983]. The surface boundary conditions for potential temperature take the classic form:

$$
\left.K_{H} \frac{\partial T}{\partial z}\right|_{z=\eta}=\frac{Q_{T}}{\rho_{0} C_{P}}
$$

where $Q_{T}$ is the net heat flux, $C_{P}\left(4186 \mathrm{~J} \mathrm{~kg}^{-1} \mathrm{~K}^{-1}\right)$ is the specific heat capacity of pure water at constant pressure and $K_{H}$ is the vertical heat diffusivity. The net heat flux $Q_{T}$ (Eq. 2) involves the balance between surface solar radiation $\left(Q_{S}\right)$, the net long-wave radiation $\left(Q_{B}\right)$, the latent $\left(Q_{E}\right)$ and sensible $\left(Q_{H}\right)$ heat fluxes.

For the salinity flux we consider the water balance:

$$
\left.K_{H} \frac{\partial S}{\partial z}\right|_{z=\eta}=(E-P-R) S+C\left(S^{*}-S\right)
$$

where $\mathrm{E}$ is the evaporation rate, $\mathrm{P}$ the precipitation rate, $\mathrm{R}$ is the river runoff and $\mathrm{S}$ is the surface model salinity at the first level. In our simulations the runoff $\mathrm{R}$ is set to 0 because of the absence of rivers with significant discharge. The last term of Eq. (3) is the salinity flux correction and accounts for the imperfect knowledge of E-P (P especially). $\mathrm{S}^{*}$ is the monthly mean sea climatology surface salinity from Med12 dataset.

The Model domain. The region covered by the present study includes the Tunisian continental Shelf, the Sicily Strait and the adjacent areas. The model domain (Fig. 1) extends from $8.8^{\circ} \mathrm{E}$ to $17^{\circ} \mathrm{E}$ and from $31^{\circ} \mathrm{N}$ to $40^{\circ} \mathrm{N}$. The horizontal grid resolution is chosen to be $1 / 32^{\circ}$ in both longitudinal and latitudinal directions, which corresponds to $3.5 \mathrm{~km}$ in the longitude/latitude. The grid resolution is chosen to be $1 / 32^{\circ}$ for a better representation of the mesoscale eddy activity and of the exchanges through the Strait of Sicily. This resolution is below the first internal Rossby radius of deformation, about $10 \mathrm{~km}$ long [Send et al., 1999]. A grid spacing in $\sigma$ is used in the vertical with 30 vertical levels. For numerical stability, the external time step $\Delta \mathrm{t}$ is set to $8 \mathrm{~s}$ with an internal integration every $240 \mathrm{~s}$, in order to satisfy the CFL condition $\Delta t<\Delta s / \sqrt{2 g h}$, where $\Delta \mathrm{s}$ is the minimum grid length.

Bathymetry and initial conditions. The model bathymetry is deduced from Smith and Sandwell topography database [Smith, Sandwell, 1997] by a bilinear interpolation of the depth data onto the model grid. The resulting bathymetry is shown in 


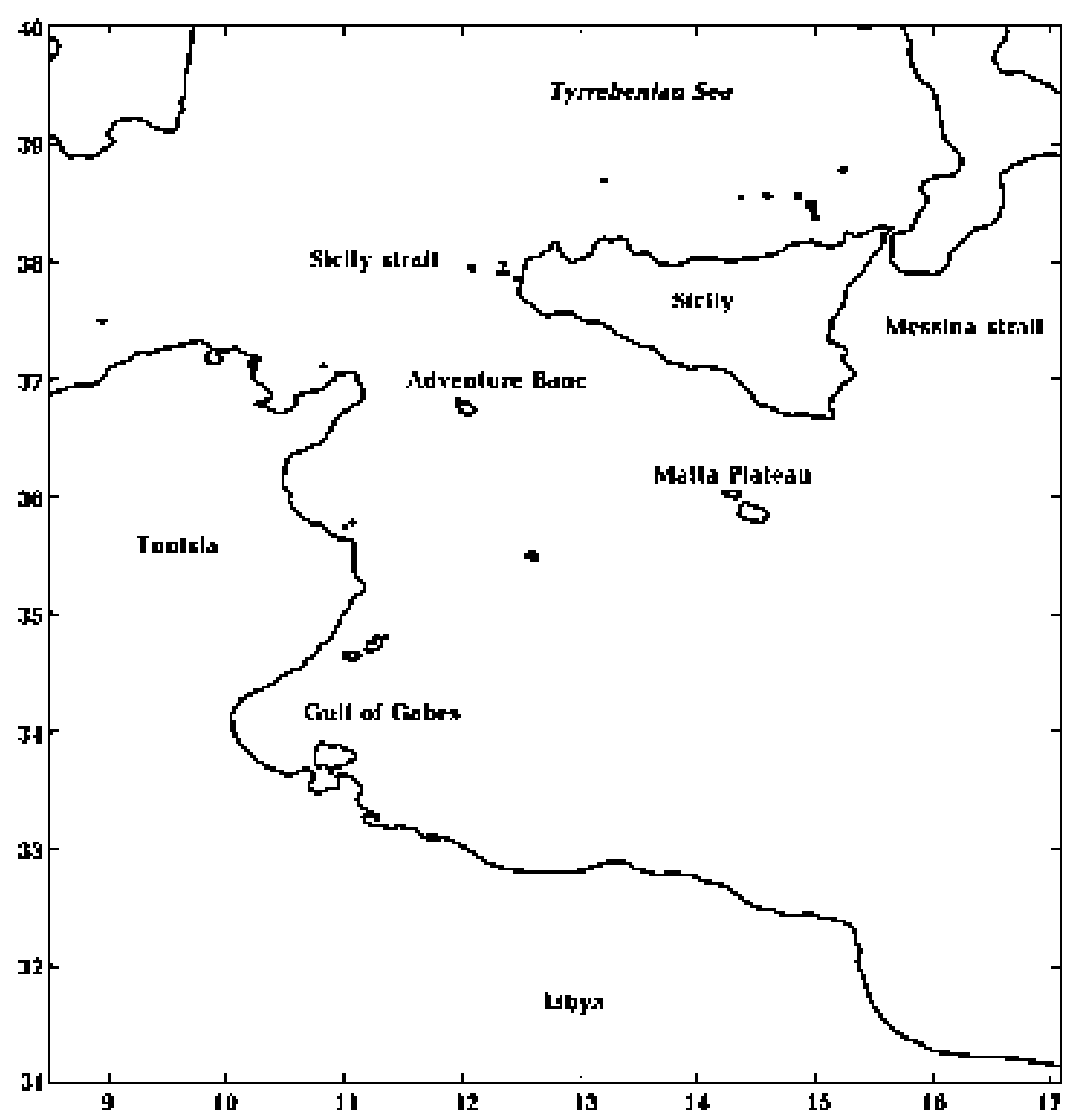

Fig. 1. Model domain and the main subbasins.

Fig. 2. It shows the main features of the modelled area geometry which is mainly characterised by the Tunisian shelf, the Adventure Bank and the Malta plateau where depths are less than $100 \mathrm{~m}$ and a much deeper eastern area with a maximum depth exceeding $2000 \mathrm{~m}$. The Tunisian continental shelf is very wide and covers a large of the Strait. In the Gulf of Gabes, the bathymetry is shallower than $30 \mathrm{~m}$ for large stretches away from the coast. The isobath $100 \mathrm{~m}$ is $200 \mathrm{~km}$ away from the coast.

The model was initialized with the temperature and salinity fields provided by the MEDATLAS monthly climatology [MEDAR/MEDATLAS Group., 2002].

Lateral open boundary conditions. The model has four open boundaries located in the southern Tyrrhenian Sea (along $39.5^{\circ} \mathrm{N}$ ), in the Sardinia Channel (along $9^{\circ} \mathrm{E}$ ) and in the open Ionian Sea (along $17^{\circ} \mathrm{E}$ ). At the lateral open boundaries the regional model receives information of temperature, salinity and velocity fields from coarse resolution basin scale model MED12 [Lebeaupin Brossier et al., 2013]. Lateral open boundary conditions are defined through a simple off-line one way nesting technique that represents an efficient way to downscale the model solutions from the basin-scale $(9 \mathrm{~km}$, the coarse model) to the subregional scale $(3.4 \mathrm{~km})$. It has been largely used in numerical weather predictions and recently in numerical oceanography to simulate the hydrodynamics of limited coastal areas [Sorgente et al., 2003; Drago et al., 2003; Oddo, Pinardi, 2008]. The monthly mean values of temperature, salinity, total velocity were transferred from the coarse spaced grid of MED12 [Lebeaupin Brossier et al., 2013] to the finely spaced grid of the ROMS open boundaries through an off-line, one-way asynchronous nesting. On the vertical plane, the coarse and fine resolution models have different vertical coordinate systems. The coarse resolution model uses a z-level discretization model, while the high resolution model uses a sigma-coordinate system. The 


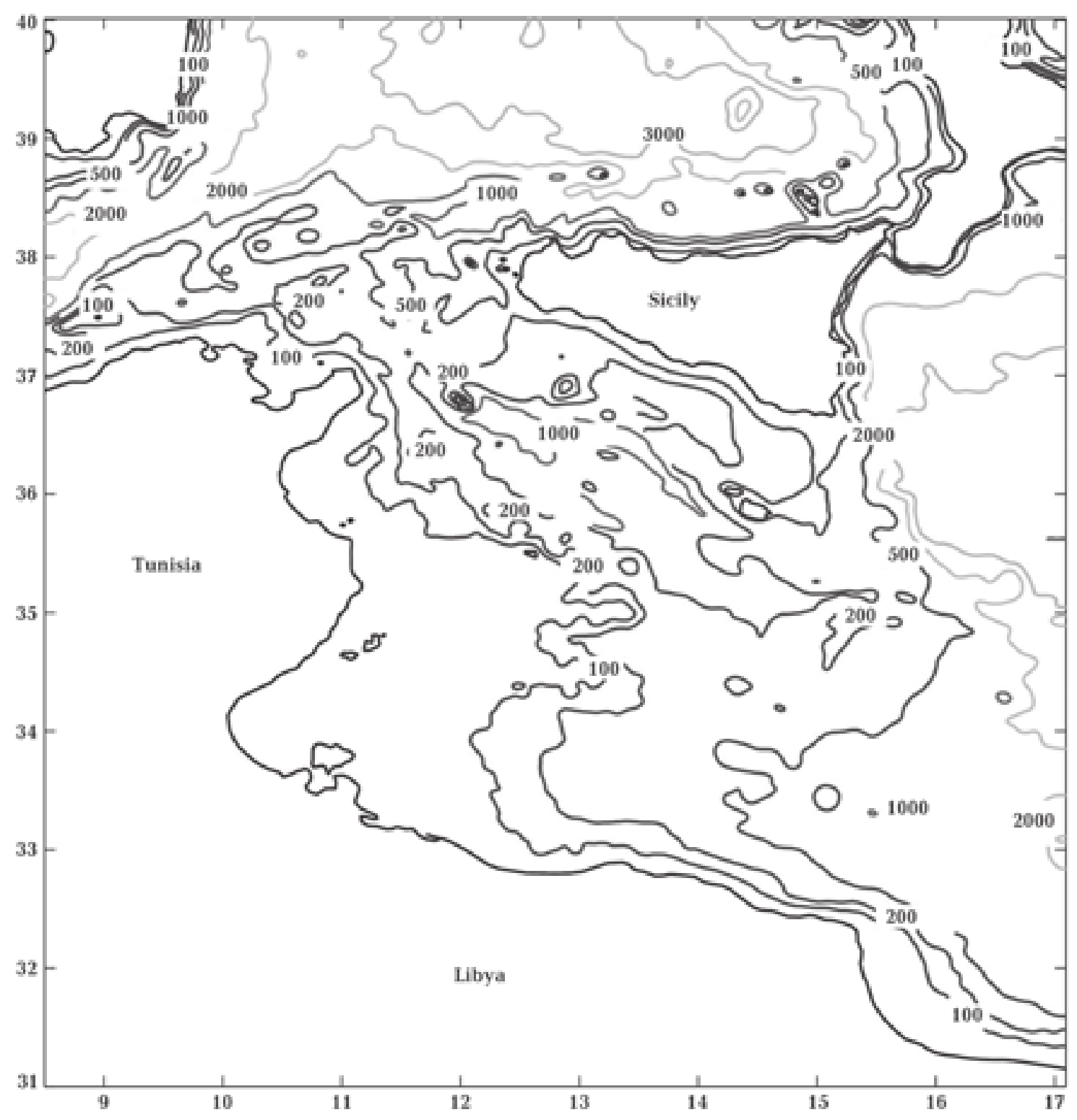

Fig. 2. Bathymetry (in m) in the central Mediterranean Sea.

main advantage with the latter vertical discretization is that a smooth representation of the bottom topography can be obtained. It has been shown [Bell, 1997] that, especially with finer grids, the step structure of a z-level model can lead to vorticity errors and consequently, to errors in the barotropic component of the flow, leading to rather large temperature errors. In the sigma-coordinate system, the top numerical level follows the free sea surface, while the lowest numerical level follows the bottom depth.

Results. Surface circulation. The schematic of the surface circulation in the Central Mediterranean Sea was investigated by several authors
[Onken et al., 2003; Béranger et al., 2004; Astraldi et al., 1996; Ben Jaber et al., 2013]. The Atlantic water (AW) enters the Mediterranean Sea through the Strait of Gibraltar, becoming warmer and saltier along the African coast and constituting the origin of the Modified Atlantic Water (MAW) proceeding towards east [Warn-Varnas et al., 1999]. In the Sardinia Channel the MAW is partially deviated northward by the shallow Tunisian Skerki Bank [Manzella et al., 1990] and then divides into two main branches under the effect of the bathymetry. The first branch directly flows into the Tyrrhenian Sea along the northern coast of Sicily [Astraldi et al., 1996], while the second turns southward into 
the Sicily Channel as a strong and narrow jet. Instead of these efforts, some uncertainties remain concerning the behavior of the veins crossing the Strait of Sicily, in particular the path of the main flow along the Tunisian coast as well as its width.

Fig. 3 shows the monthly mean of sea surface salinity and sea surface temperature fields in April during the $11^{\text {th }}$ year of the simulation. This presentation was chosen, on one hand, to figure out the major water masses of the Central Mediterranean Sea surface and, on the other hand, to specify their pathway. Indeed, the MAW can be traced by its low salinity and temperature values. It is evident from Fig. 3 that the MAW invades the strait of Sicily and continues to flow eastward to the Tyrrhenian Sea and after crossing the strait, the major water flux follows the isobath $200 \mathrm{~m}$ and occupies a large part of the Tunisian continental shelf and the rest goes to the south coast of Sicily. The monthly distribution of the simulated salinity field increases from the eastern Tunisian shelf to the eastern side of the domain, with a gradual modification of surface properties of the MAW. The Gulf of Gabes, a region characterized by a shallow bathymetry, is characterized by strong anomalies of the temperature and salinity. To better identify the pathway of the modified Atlantic water in the eastern basin, we show in Fig. 4 the velocity vectors at a depth of $20 \mathrm{~m}$ in summer and in winter during as simulated by our model. It is apparent from Fig. 4 that in the Sardinia Channel the MAW is partially deviated northward by the shallow Tunisian Skerki Bank in agreement with observations and then divides into three main branches under the effect of the bathymetry [Herbaut et al., 1998]. One branch enters the Tyrrhenian Sea, flowing along the northern Sicilian coast as Bifurcation Tyrrhenian Current (BTC); the other two MAW veins flow into to the eastern Mediterranean basin crossing the Sicilian Channel, in agreement with previous studies [Astraldi et al., 1999; Sorgente et al., 2003; Béranger et al., 2004]. The main flow in the crossing the Sicilian Channel is along the Tunisian coast and gives rise to the Atlantic Tunisian Coast (ATC), while the smaller flux on the southern Sicilian shelf gives rise to the northern meandering AIS-Atlantic Ionian Stream [Robinson et al., 1999].

Our simulations show that the ATC flows southward over the Tunisian continental slope with an associated salinity minimum (see Fig. 4) as a relatively strong current decreasing progressively its velocity south-eastward. It flows approximately following the $200 \mathrm{~m}$ isobaths. The semipermanent features linked to the meanders of the AIS during summer described by several studies [Robinson
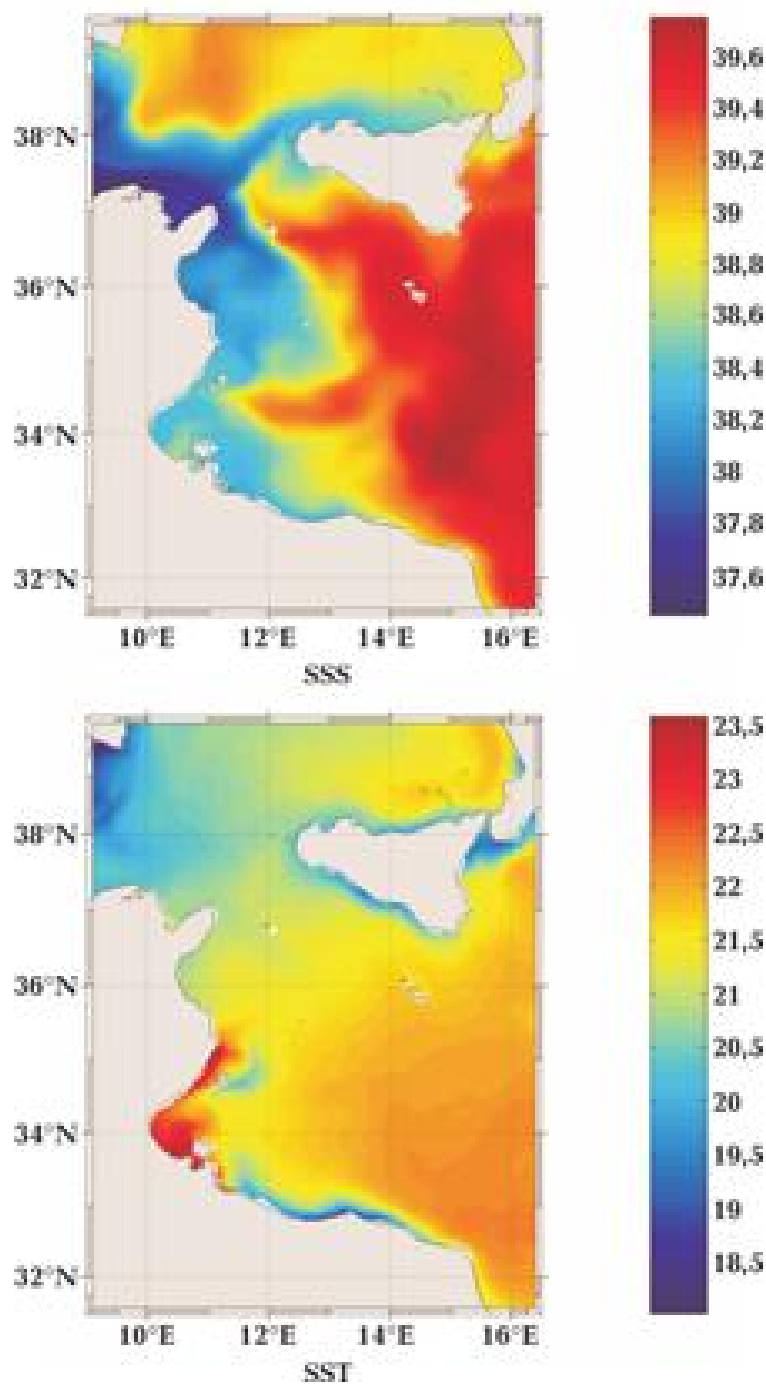

Fig. 3. Monthly mean of sea surface salinity (SSS) and potential temperature (SST) in April.

et al., 1999; Lermusiaux, 1999; Sorgente et al., 2003; Lermusiaux, Robinson, 2001; Béranger et al., 2004], namely, the cyclonic Adventure Bank Vortex (ABV hereafter), the anti-cyclonic Maltese Channel Crest (MCC hereafter), the cyclonic Ionian Shelf break Vortex (ISV hereinafter), and the intermittent cyclonic Messina Rise Vortex (MRV hereafter) are well reproduced (see Fig. 4). These meanders and eddies vary in strength, size and shape, shift their positions, and interact. They are partly controlled by topographic features, coastal geometry, and thermohaline boundary forcing. The seasonal variability of the ATC and the AIS is significantly different. The southern flow along the African coast reaches its maximum in late autumn, in agreement with the observations [Astraldiet al., 1996]. The MAW vein close to the southern Sicilian coast is most conspicuous during 

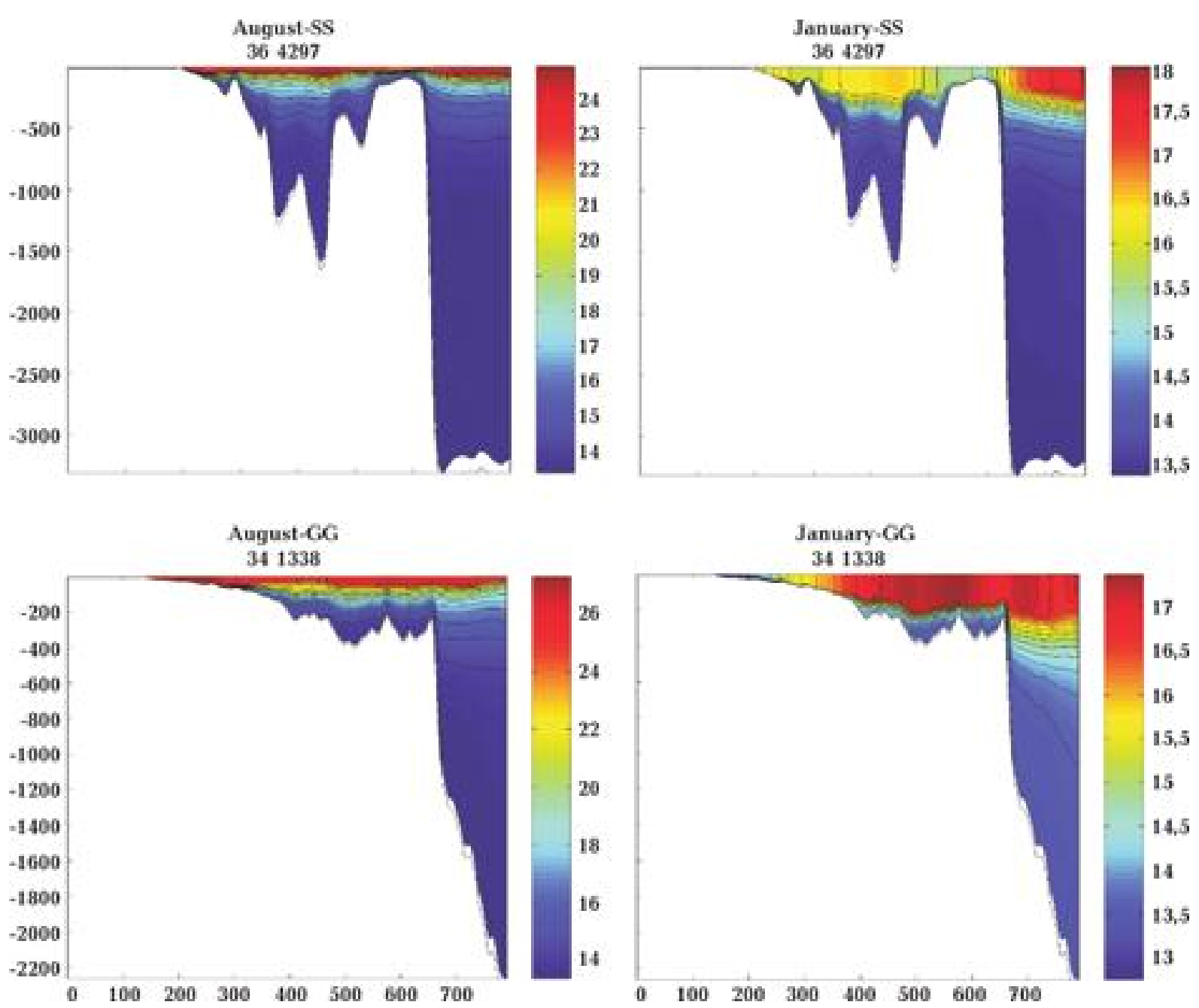

Fig. 6. Monthly mean vertical sections of salinity and potential temperature in August and January along latitude $36,4^{\circ} \mathrm{N}$ (Sicily strait, SS section), and along latitude $34,1^{\circ} \mathrm{N}$ (Gulf of Gabes, GG section).

summer and autumn, proceeding eastward along the swift topographically controlled AIS. During winter, the MAW fills the whole extent of the Strait up to the westernmost tip of the southern Sicilian shelf. Starting from spring, this MAW then starts to progressively detach from the surface, taking the form of a subsurface core at a depth of about $60 \mathrm{~m}$ in autumn [Sorgente et al., 2003].

For the MAW branch, which entered the Tyrrhenian Sea, the trajectory varied with season. In summer situation, the circulation is characterized by many eddies. In particular, a big anticyclonic eddy is seen off northwestern Sicily (Fig. 4, a), which has been identified from satellite altimeter data [Boukthir et al., 2007]. On the other hand, in winter, the MAW flowed along the northern coast of Sicily and cyclonically in the Tyrrhenian Sea (Fig. $4, b$ ). The seasonal variability of the surface circulation off northwestern Sicily deduced from our numerical simulation has been confirmed from the analysis of eleven years of Topex/Poseidon and ERS1/2 data [Abdennadher, Boukthir, 2007].

Circulation in the eastern Tunisian shelf. The circulation in the eastern Tunisian shelf is characterized mainly by a strong and relatively cooler eastward flow, entailing the Modified Atlantic Water southward. This current, called the Atlantic Tunisian current, is following closely to the African shelf edge. South of Lampedusa Island, the ATC splits into two branches at $34.5^{\circ} \mathrm{N}$. One branch flows into the Ionian Sea (branch 3, Fig. 5,a), while the second flows south-eastward and bifurcates into two veins (1) and (2) as illustrated in Fig. 5. The first one (1) entered the Gulf of Gabes and the second one (2) flows approximately following the $200 \mathrm{~m}$ isobaths until Libya coast which can be considered as the eastward extension of ATC along the Libyan coast [Poulain, 

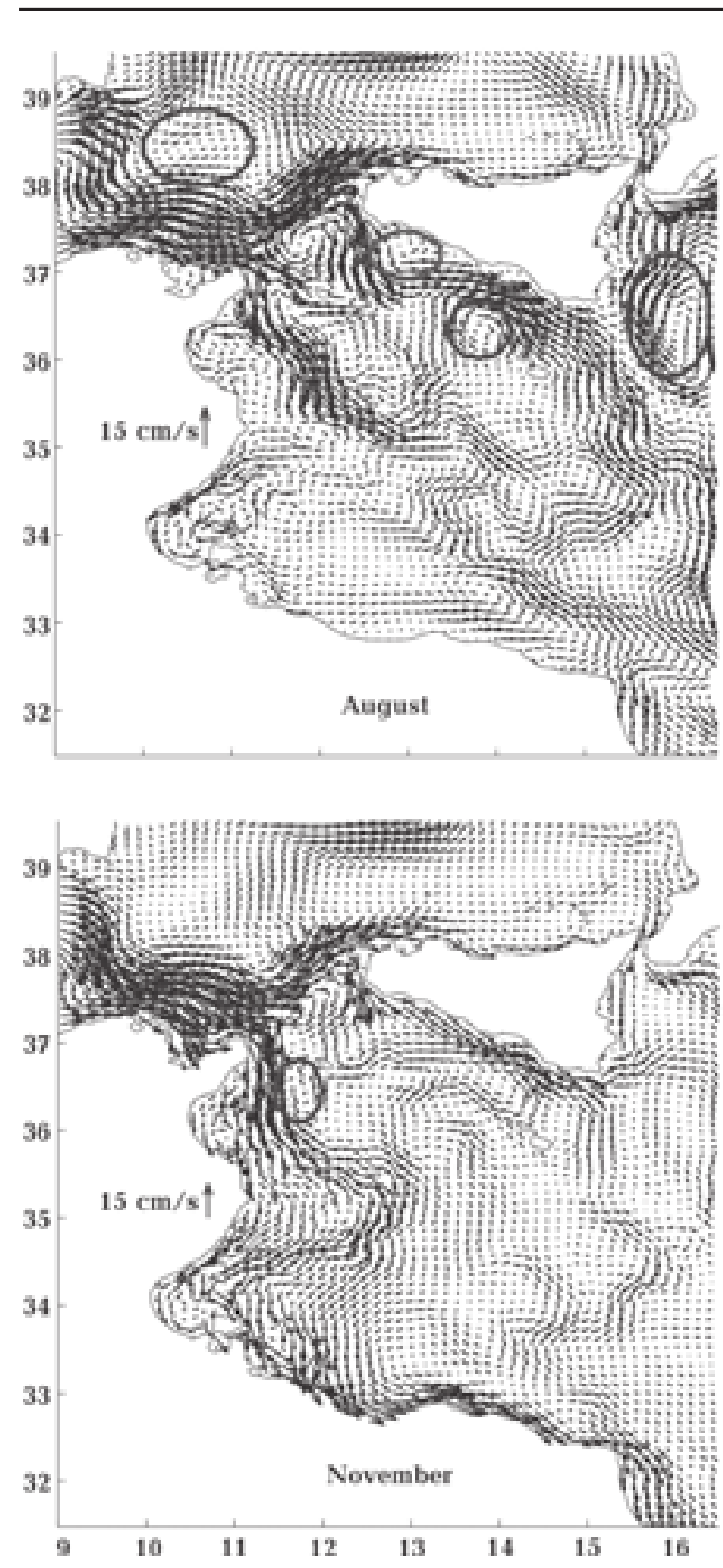

Fig. 4. Horizontal current at depth $20 \mathrm{~m}$ in summer (upper) and winter (lower).

Zambianchi, 2007; Napolitano et al., 2003]. The ATC is characterized by an important seasonal variability. During autumn-winter period, the ATC invades the Tunisian continental shelf (Fig. $5, c, d$ ) and there is no more flow toward the Ionian Sea. Our simulations show that the ATC exists in summer (Fig. $5, b$ ) but it is the subject of high interannual variability. Indeed, the ATC becomes weak in summer and may even disappear during some other years. This could explain the contradiction between those who assert that the ATC does not exist in summer [Béranger et al., 2004] and those who assert its existence during the same season [Napolitano et al., 2003]. The dynamics of the area is also characterized by a permanent anticyclonic gyre located in the Gulf of Hammamet and by a pair of small-scale anticyclonic gyres during spring/summer (see Fig. 5, $a, d$ ), located off the Libyan coast between $14^{\circ} \mathrm{E}$ and $15.5^{\circ} \mathrm{E}$.

Vertical structures. In order to assess the vertical structures we have selected two vertical sections, one in the Strait of Sicily at $36.43^{\circ} \mathrm{N}$ (SS hereafter) and the second in the Gulf of Gabes at $34.13^{\circ} \mathrm{N}$ (GG hereafter) (see Fig. 6 on p. 80). Our results reproduce qualitatively well the vertical distribution of the potential temperature. Its distribution (see Fig. 5) shows that during the summer period (August) the vertical stratification is stronger than during winter (January) in SS and GG. The thermocline is clearly established in summer. During winter, a period of strong wind, the latter has been acting at the sea surface and enhances the vertical mixing and consequently reduces the strength of the vertical stratification. In winter, the potential temperature from bottom to surface ranges from $13.5^{\circ} \mathrm{C}$ to $18^{\circ} \mathrm{C}$ for SS vertical section and from $13.75^{\circ} \mathrm{C}$ to $17.5^{\circ} \mathrm{C}$ in the GG vertical section. In August, the potential temperature at the sea surface increases in both sections since it is about $25^{\circ} \mathrm{C}$ in $\mathrm{SS}$ section and $27^{\circ} \mathrm{C}$ in GG section. This high summer temperature is due to the strong positive surface heat fluxes and the shallow bathymetry in the Gulf of Gabes. It is interesting to note that the temperature at the bottom of both sections SS and GG is almost the same during January and August. The thermocline is clearly established in summer and the mixed layer is deeper in winter than in summer due to the action of the wind, particularly strong during winter.

Conclusion. This study aimed to obtain a coherent picture of the modified Atlantic water pathway in the Strait of Sicily and the adjacent areas, particularly along the Tunisian coasts. The surface circulation has been inferred from a high resolution general circulation model of the Central Mediterranean Sea. The monthly mean values of temperature, salinity, total velocity and elevation were transferred from the coarse spaced grid of MED12 to the finely spaced grid of the ROMS open boundaries through an off-line, oneway nesting. It is evident that the high resolution model is able to simulate the major water masses and the surface circulation patterns in the central Mediterranean. Particularly, it reproduces well the AIS flow and variability, including the associated characteristic structures such as the Adventure Bank Vortex, the Maltese Channel Crest, the Io- 

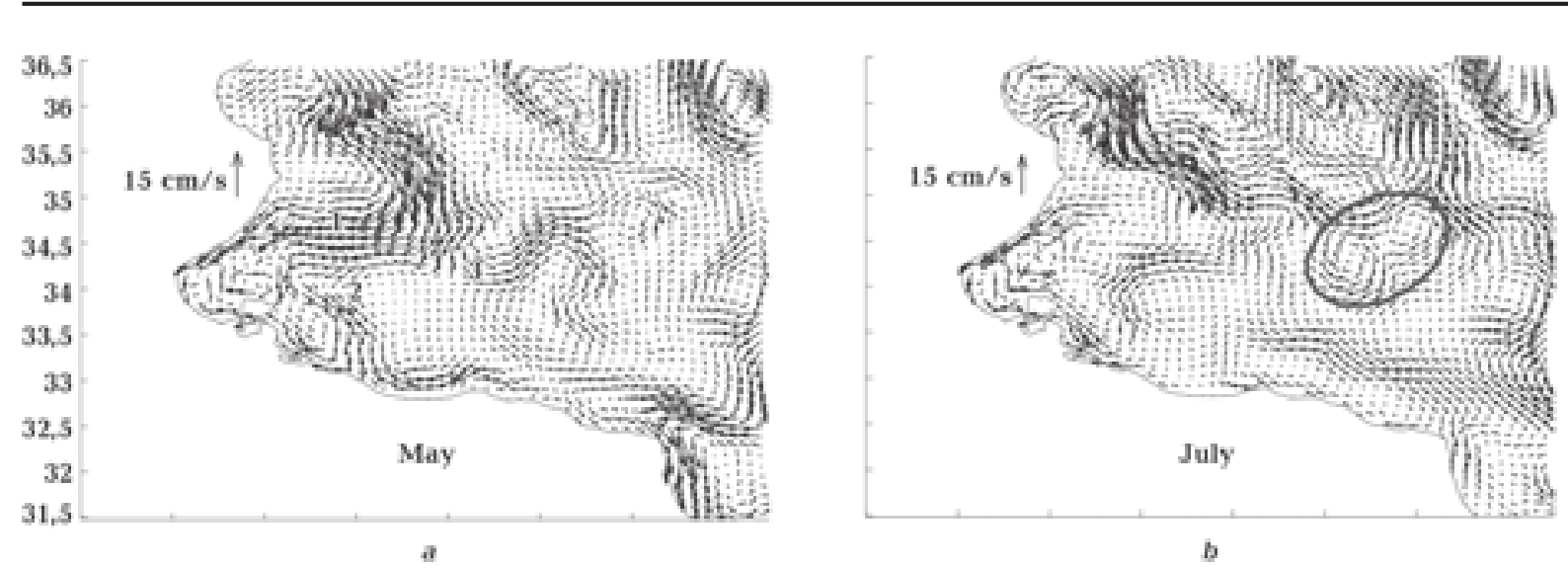

b
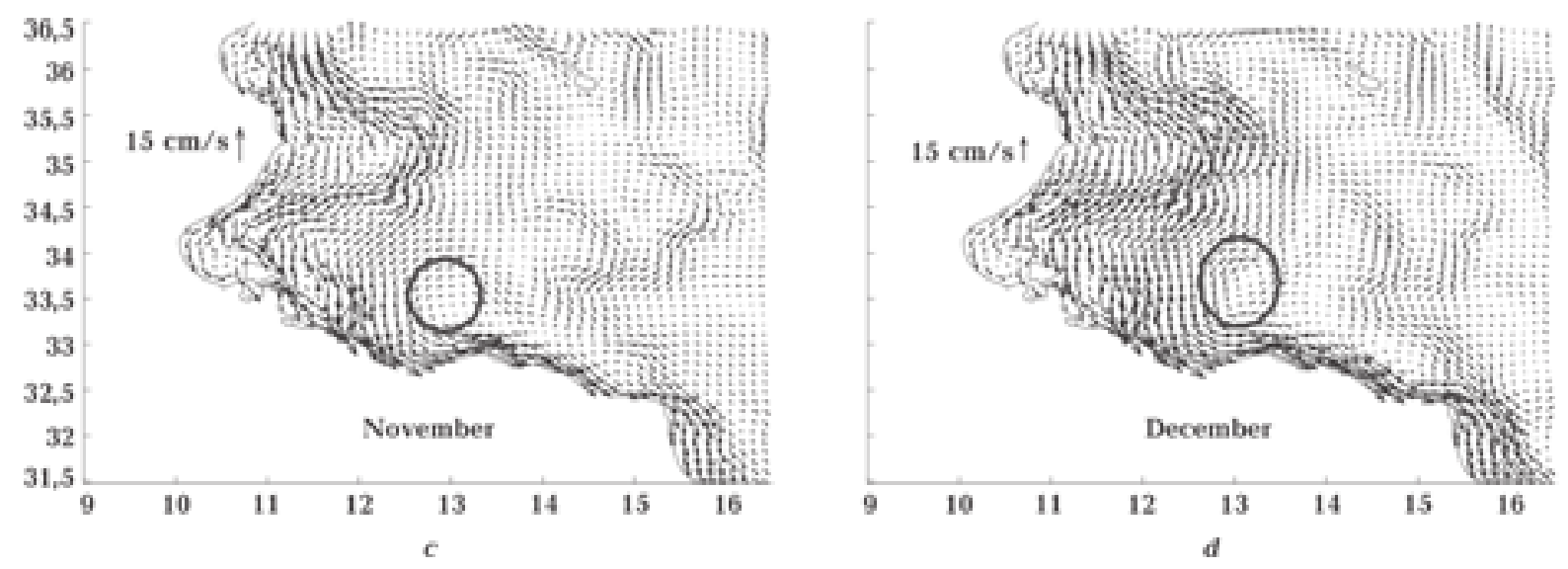

Fig. 5. Horizontal current at depth $20 \mathrm{~m}$ in the Gulf of Gabes in spring (a), summer (b), autumn (c), and winter (d).

nian Bank Vortex and the overshooting into the northern Ionian Sea. Our results are compared reasonably with those deduced from observations [Astraldi et al., 1996; 2002; Sorgente et al., 2011]. The simulated circulation reproduces the branching of the modified Atlantic water into two main streams. The southern branch follows the Tunisian shelf edge and spreads over the Tunisian and the wide shallow Libyan continental platform, particularly in autumn. The northern branch flows along the Sicilian shelf. Both have a strong seasonal variability, particularly in their volume transport. The path of the Atlantic Tunisian Current and its variability are clarified, particularly south of Lampedusa Isle. The Atlantic Tunisian Current flows eastward mainly along the $200 \mathrm{~m}$ isobath. South of Lampedusa Isle, it splits into two main branches. The first branch directly flows toward the southern part of the Levantine basin, while the second is flowing over the Tunisian shelf. The latter divides into two veins, the first one invades the Tunisian shelf in the Gulf of Gabes and recirculates anticyclonally on the shelf, while the second continues flowing southeastward as an important coastal current and comes close to the
Libyan coast, giving rise to a strong coastal jet near the Libyan current. This scheme is different from an earlier ones estimated from models of coarse resolution. A small cyclonic vortex develops downstream Cape Bon and it seems that it constrains the modified Atlantic water towards the Tunisian slope increasing its velocity. However, the existence of this mesoscale feature should be confirmed by oceanographic surveys. The Atlantic Tunisian Current is stronger than the Atlantic Ionian Stream from autumn to winter. In January, the Atlantic Ionian Stream is close to the Sicilian coast, and the Atlantic Tunisian current close to the Tunisian coast. The modified Atlantic water is colder in the Atlantic Ionian Stream than in the Atlantic Tunisian current due to mixing with upwelling waters [Béranger et al., 2004]. In July, the Atlantic Ionian Stream meandered, whereas the Atlantic Tunisian current appears weak or not present at all, in agreement with previous studies [Sorgente et al., 2003; Bérangeret al., 2005]. Nevertheless, our results show that the Atlantic Tunisian current is clearly present in July for year 2006, suggesting a possible interannual variability of this current. We believe that the Atlantic Tuni- 
sian current is present during the year, although it is difficult to identify in July, because of the recirculation in the Sicily Channel.

Acknowledgements. The authors are supported by Ministry of Higher Education and Scientific Research Tunisia through UR11ES88. The boundary conditions were gracefully supplied by Dr. Béranger and they arise from simulations of the circulation of the Mediterranean Sea realized within the framework of the project MORCEMED (funded by the GIS-Climate) and the project SiMED (funded by GMMC).

\section{References}

Abdennadher J., Boukthir M., 2007. Seasonal and interannual variations of the sea surface circulation in the central Mediterranean Sea derived from 11 years of Topex/Poseidon and ERS1/2 data. Online J. Earth Sci. 1 (4), 180-187.

Astraldi M., Balopoulos S., Candela J., Font J., Gacic M., Gasparini G. P., Manca B., Theocharis A., 1999. The role of straits and channels in understanding the characteristics of Mediterranean circulation, Progress in Oceanography 44, 65-108.

Astraldi M., Gasparini G. P., Sparnocchia S., Moretti M., Sansone E., 1996. The characteristics of the water masses and the water transport in the Sicily Strait at long time scales the eastern and western Mediterranean through the Strait of Sicily. Bulletin de l'Institut Oceanographique, Monaco, CIESM Science Series (2), 95-115.

Astraldi M., Gasparini G. P., Vetrano A., Vignudelli S., 2002. Hydrographic characteristics and interannual variability of water masses in the central Mediterranean: a sensitivity test for longterm changes in the Mediterranean Sea. Deep-Sea Res. Pt. I, 49, $661-680$.

Bell M. J., 1997. Vortex stretching and bottom torque in the Bryan-Cox ocean circulation model. The Met. Office. Applications T. N. 17.

Ben Jaber I., Abdennadher J., Boukthir M., 2013. Seasonal Variability of the Atlantic Tunisian current derived from a high resolution model, $40^{\text {th }}$ CIESM Congress.

Boukthir M., Abdennadher J., Jebali J., 2007. Sea Surface Circulation within the Eastern Mediterranean derived from Satellite Observations of Altimetry and Wind. Geophys. J. 29(1), 144-152.

Brasseur P., Beckers J. M., Brankart J. M., Schoenauen $R ., 1996$. Seasonal temperature and salinity fields in the Mediterranean Sea: climatological analyses of a historical data set. Deep-Sea Res. Pt. I, 43, 159-192.

Bŭranger K., Mortier L., Crŭpon M., 2005. Seasonal variability of water transport through the Straits of Gibraltar, Sicily and Corsica derived from a high- resolution model of the Mediterranean circulation. Prog. Oceanogr. 66, 341-364.

Bŭranger K., Mortier L., Gaspirini G.-P., Gervasio L., Astraldi M., Crŭpon M., 2004. The dynamics of the Sicly strait: a comprehensive study from observations and models. Deep-Sea Res. Pt. II, 51, 411440 .

Drago A. F., Sorgente R., Ribotti A., 2003. A high resolution hydrodynamic 3-D model simulation of the Malta shelf area. Ann. Geophys. 21, 323-344.

Gasparini G. P., Bonanno A., Zgozi S., Basilone G., Borghini M., Buscaino G., Cuttitta A., Essarbout N., Mazzola S., Patti B., Ramadan A. B., Schroeder K., Bahri T., Massa F., 2008. Evidence of a dense water vein along the Libyan continental margin. Ann. Geophys. 26, 1-6. doi:10.5194/angeo-26-1-2008.

Gasparini G. P., Ortona A., Budillon G., Astraldi M. Sansone E., 2005. The effect of the Eastern Mediterranean transient on the hydrographic characteristics in the Straits of Sicily and in the Tyrrhenian Sea. Deep-Sea Res. Pt. I, 52, 915-935.

Hamad N., Millot C., Taupier-Letage I., 2005. A new hypothesis about the surface circulation in the eastern basin of the Mediterranean Sea. Prog. Oceanogr. 66(2-4), $287-298$.

Hellerman S., Rosenstein M., 1983. Normal monthly wind stress over the world ocean with error estimates. J. Phys. Oceanogr. 13, 1093-1104.

Herbaut C., Codron F., Crepon M., 1998. Separation of a Coastal Current at a Strait Level: Case of the Strait of Sicily. J. Phys. Oceanogr. 28, 1346-1362.

Lebeaupin Brossier C., Drobindki P., Beranger K., Bastin $S$., Orain F., 2013. Ocean memory effect on the dynamics of coastal heavy precipitation preceded by a mistral event in the northewestern Mediterranean. Q. J. Roy. Meteorol Soc. 139, 1583-1597.

Lermusiaux P. F. J., 1999. Estimation and study of mesoscale variability in the Strait of Sicily. Dynam. Atmos. Oceans 29, 255-303.

Lermusiaux P. F. J., Robinson A. R., 2001. Features of 
dominant mesoscale variability, circulation patterns and dynamics in the Strait of Sicily. Deep-Sea Res. Pt. I, 48, 1953-1997.

Manzella G. M. R., Hopkins T. S., Minnett P. J., Nacini E., 1990. AtlanticWater in the Strait of Sicily. $J$. Geophys. Res. 95, 1569-1575.

Manzella G. M. R., La Violette P., 1990. The seasonal variation of water mass content in the western Mediterranean and its relationship with the inflow through the Strait of Gibraltar and Sicily. J. Geophys. Res. 95(C2), 1623-1626.

MEDAR/MEDATLAS Group, 2002. MEDAR/MEDATLAS 2002 Database. Cruise inventory, observed and analyzed data of temperature and bio-chemical parameters (4 CD-ROMs).

Mellor G. L., Yamada T., 1982. Development of a turbulence closure model for geophysical fluid problems. Rev. Geophys. Space Phys. 20, 851-875/

Napolitano E., Sannino G., Vincenzo A., Marullo S., 2003. Modeling the baroclinic circulation in the area of the Sicily channel: The role of stratification and energy diagnostics. J. Geophys. Res. 108(C7), 3230. doi:10.1029/2002JC001502.

Oddo P., Pinardi N., 2008. Lateral open boundary conditions for nested limited area models: A scale selective approach. Ocean Model. 20, 134-156.

Onken R., Robinson A. R., Lermusiaux P. F. J., Haley P. J., Aanderson A. L., 2003. Data-driven simulations of synoptic circulation and transports in the Tunisian-Sardinia-Sicily region. J. Geophys. Res. 108(C9), 8123-8136.

Poulain P. M., Zambianchi E., 2007. Surface circulation in the central Mediterranean Sea as deduced from Lagrangian drifters in the 1990s. Cont. Shelf Res. 27, 981-1001.
Robinson A. R., Sellschopp J., Warn-Varnas A., Anderson L. A., Lermusiaux P. F. J., 1999. The Atlantic Ionian Stream. J. Marine Systems 20, 129-156.

Sammari C., Millot C., Taupier-Letage I., Stefani A., Brahim M., 1999. Hydrological characteristics in the Tunisian-Sardinia-Sicily area during spring 1995. Deep-Sea Res. Pt. I, 46, 1671-1703.

Send U., Font J., Krahmann G., Millot C., Rhein M. Tintor J., 1999. Recent advances in observing the physical oceanography of the western Mediterranean. Progress in Oceanography, 44, 37-64.

Shchepetkin A., McWilliams J., 2005. The regional oceanic modeling system (ROMS): a split-explicit, free-surface, topography-following-coordinate oceanic model. Ocean Model 9, 47-404.

Smith W. H. F., Sandwell D. T., 1997. Global sea floor topography from satellite altimetry and ship depth soundings. Sciences 277, 1956-1962.

Sorgente R., Drago A. F., Ribotti A., 2003. Seasonal variability in the Central Mediterranean Sea circulation. Ann. Geophys. 21, 299-322. doi:10.5194/angeo-21-299.

Sorgente R., Olita A., Oddo P., Fazioli L., Ribotti A., 2011. Numerical simulation and decomposition of kinetic energy in the Central Mediterranean: insight on mesoscale circulation and energy conversion. Ocean Sci. 7, 503-519.

Vetrano A., Gasparini G. P., Molcard R., Astraldi M., 2004. Water flux estimates in the central Mediterranean Sea from an inverse box model. J. Geophys. Res. 109, 1-24, C01019.

Warn-Varnas A., Sellschops J., Haley Jr. P. J., Leslie W. G., Lozano C. J., 1999. Strait of Sicily water masses. Dynam. Atmos. Oceans 29, 437-469. 